\title{
TEXTURE ANALYSIS OF STARFRUIT (Averrhoa carambola) CHIPS PRE-TREATED WITH GLUCOSE SYRUP AND OSMOTIC DEHYDRATION
}

\author{
SITI RADHIAH OMAR ${ }^{1,2^{*}}$, SYAFIQAH ABDUL RAZAK ${ }^{1}$ and NUR ZAZARINA RAMLY ${ }^{1}$ \\ ${ }^{1}$ Faculty of Science and Technology, Universiti Sains Islam Malaysia, \\ 71800, Bandar Baru Nilai, Negeri Sembilan \\ ${ }^{2}$ IHRAM, International Fatwa and Halal Centre (iFFAH), Universiti Sains Islam Malaysia, \\ Bandar Baru Nilai, 71800, Nilai, Negeri Sembilan \\ *E-mail: sitiradhiah@usim.edu.my
}

Accepted 12 September 2020, Published online 25 October 2020

\begin{abstract}
Osmotic dehydration (OD) of starfruit chips by glucose syrup was chosen as the osmotic agent (OA) in this study as it is believed to confer a desirable result in the final product. As in this study, the concentration of glucose syrup that was used is 30,40 and $50^{\circ}$ Brix with soaking temperature of $20^{\circ} \mathrm{C}$ to $60^{\circ} \mathrm{C}$ and soaking time of $20 \mathrm{~min}$ to $60 \mathrm{~min}$. The result showed that higher water loss and lower solid gain of starfruits obtained as the higher temperature and glucose syrup concentrations were used. Meanwhile, processing of osmo-dried starfruits into chips were done by stir frying with canola oil. The use of glucose syrup with concentration of $50^{\circ} \mathrm{B}, 60^{\circ} \mathrm{C}$ temperature and 60 min soaking time produced the highest hardness and crispness of starfruit chips with the lowest moisture content. Test of significance $(p<0.05)$ in results obtained from this study were determined using Minitab 18 software as one-way Analysis of Variance (ANOVA) and Tukey-Test. In general, OD pretreatment could be proved as an effective technique for food industries to develop fried starfruit chips with improved texture quality.
\end{abstract}

Key words: Osmotic dehydration, pre-treatment, glucose syrup, starfruit chips

\section{INTRODUCTION}

Starfruits, Averrhoa carambola has been cultivated for many years in Southeast Asia and Malaysia. Dasgupta et al. (2013) stated that carambola, which comes from the family of Oxalidaceae is originated in Ceylon and Moluccas. The five-pointed star shape is its unique characteristic (Leelarungrayub et al., 2016). Its taste can be described as the combination of an apricot and a passion fruit since it has a sweet-watery pulp (Macoboy, 1982). Today, the development of technology has led to the creativity of people into making the raw fruits to an edible and interesting new product, for example, fruit chips. This fruit chips can be processed through drying method to produce a new food product. Osmotic dehydration (OD) is one of the techniques which can be used.

OD is defined as the phenomenon of removal of water from lower concentration of solute to

\footnotetext{
* To whom correspondence should be addressed.
}

higher concentration through semi permeable membrane, which leads to a balanced condition for both sides of membranes (Tiwari, 2005). A few studies have succeeded in proving that OD is the best and latest drying method that can be applied in fruits. For example, El-Aouar et al. (2006) stated that his study in observing the OD of papaya slices was a success. Osmotic agent (OA) plays a vital role in OD. Some of the OA usually used in OD are sucrose, glucose, and sodium chloride $(\mathrm{NaCl})$. In OD process, there are few variables that can be controlled such as solutes concentration $\left({ }^{\circ} \mathrm{Brix}\right)$, solution temperature $\left({ }^{\circ} \mathrm{C}\right)$ and soaking time of fruits or vegetables in the solution which is usually taken in minutes (Yadav \& Singh, 2014). According to Chaudhari et al. (1993), the higher the concentration of syrup, the higher the rate of osmosis, which will occur in the solution. Some of the advantages of OD are only retention of colour, flavour, and quality of texture and its storage life also can be prolonged (Yadav \& Singh, 2014). 
In this study, glucose syrup is chosen as the OA for OD process as Chauhan and Kapfo (2016) stated that samples dipped in glucose syrup solution produced higher solid gain and higher water loss. To date, only a few studies that reported the effect of OD on the quality of the starfruit chips. Hence, the objectives of this study are to determine the effect of glucose syrup as OA on the water loss and solid gain of carambola and textural properties of starfruits chips.

\section{MATERIALS AND EXPERIMENTAL}

\section{Materials}

Carambola with the average weight of 35 to $40 \mathrm{~g}$, and greenish colour according to Federal Agriculture Marketing Authority (FAMA) maturity index 4 were bought at Giant Supermarket, Nilai, Negeri Sembilan. The fruits damaged at the outer layer were removed. The graded fruits were washed with chlorinated water $\left(100 \mathrm{ppm}\right.$ available $\left.\mathrm{Cl}_{2}\right)$ thoroughly. Then, the fruits were sliced manually by using a stainless-steel knife. The thickness of the slices was maintained at $1 \mathrm{~cm}$. All samples were in triplicates.

\section{Osmotic dehydration and frying}

In this study, the concentration of glucose syrup which will be used is 30,40 and $50^{\circ}$ Brix. Glucose syrup is chosen over the other OA as it is available easily and gives a desirable result in the final product. The slices were soaked in glucose solution of different concentrations $\left({ }^{\circ} \mathrm{Brix}\right)$, temperature $\left({ }^{\circ} \mathrm{C}\right)$ and soaking time ( $\mathrm{min})$. The samples were removed after the time intervals had passed and were put in a dehydrator for $2 \mathrm{hr}$ to prolong the dehydration process until the final moisture content of samples reached $14-15 \%$. During OD process, its water loss and solid gain due to the variables used in the process were recorded.

\section{Moisture content and dry matter}

The moisture content and the dry matter were computed according to the AOAC (2005). The moisture content of carambola chips was determined by using moisture analyzer (METTLER TOLEDO, HE53 230V Model, Ohio) available at Faculty of Science and Technology, USIM. All readings obtained in this experiment were in triplicates. The results for moisture content were recorded in mean \pm standard deviation value (Aida et al., 2016). The water loss and solid gain were measured using following equations by Chauhan and Kapfo, (2016):

Water loss $(\mathrm{g} / 100 \mathrm{~g})=\frac{\left(\mathrm{W}_{0}-\mathrm{W}_{1}\right)-\left(\mathrm{S}_{\mathrm{t}}-\mathrm{S}_{0}\right) \times 100}{\mathrm{~W}_{0}} \quad$ Eq. (1)
Solid gain after OD for time $\mathrm{t}(\mathrm{ST})=\left(\mathrm{S}_{\mathrm{t}}-\mathrm{S}_{0}\right) \times 100$ Eq. $(2)$

Solid gain $(g / 100 \mathrm{~g})=\frac{\left(\mathrm{S}_{\mathrm{t}}-\mathrm{S}_{0}\right) \times 100}{\mathrm{~W}_{0}}$

Where, $\mathrm{W}_{0}$ was the initial weight of sample in $\mathrm{g}, \mathrm{W}_{1}$ was the weight of slices after OD for any time, $\mathrm{t}$ in $\mathrm{g}, \mathrm{S}_{0}$ was the initial weight of solids (dry matter) in slices $(\mathrm{g}), \mathrm{S}_{\mathrm{t}}$ was the weight of solids (dry matter) in slices after OD for time $t(\mathrm{~g})$.

\section{Texture analysis}

The texture of carambola chips was measured by using TA XT-Plus Texture Analyzer in determining their hardness and crispness. Texture measurements of carambola chips were performed at room temperature $\left(25 \pm 1^{\circ} \mathrm{C}\right)$ with a slight modification by employing puncture test (Lopez \& Moreira, 2019). Carambola chips were mounted individually on a one-point-support, at a distance maintained at $15 \mathrm{~mm}$ with the punch diameter and the crosshead speed being $2 \mathrm{~mm}$ and $60 \mathrm{~mm} / \mathrm{min}$, respectively. Force versus distance curves were generated based on the puncture test and the data was analyzed by using inbuilt software of the texture analyzer.

\section{Frying conditions of the chips}

The fruits which underwent OD process were stir fried with canola oil at $170 \pm 5^{\circ} \mathrm{C}$ for $3 \mathrm{~min}$ and placed on oil-absorbing sheets to remove excess surface oil (Rodríguez-Miranda et al., 2018). At the end of cooking, about $1.5 \%$ salt was added onto the carambola chips.

\section{Experimental design and statistical analysis}

In this study, OD process of carambola was done by using glucose syrup that has 42 dextrose equivalent (DE) as the OA. The variables in this process consist of the soaking concentration which is $30 \mathrm{Brix}^{\circ}, 40 \mathrm{Brix}^{\circ}$ and $50 \mathrm{Brix}^{\circ}$, soaking temperature which is $20^{\circ} \mathrm{C}, 40^{\circ} \mathrm{C}, 60^{\circ} \mathrm{C}$ and soaking time which is $20 \mathrm{~min}, 40 \mathrm{~min}$ and $60 \mathrm{~min}$ (Table 1). Then, all the data obtained in this study were reported as mean \pm standard deviation $(n=9)$. One-way ANOVA was used to determine the statistical significance of the results $(p<0.05)$. The means were compared by Tukey test at $5 \%$ of significance. Minitab 18 software was used for statistical analysis.

Table 1. Level of variables for OD process

\begin{tabular}{llll}
\hline \multicolumn{4}{c}{ Samples of carambola slices } \\
\hline Soak solution concentration ( ${ }^{\circ}$ Brix) & 30 & 40 & 50 \\
Soaking temperature $\left({ }^{\circ} \mathrm{C}\right)$ & 20 & 40 & 60 \\
Soaking time (min) & 20 & 40 & 60 \\
\hline
\end{tabular}




\section{RESULTS AND DISCUSSION}

\section{Effective diffusivity of water and solids during the OD of pretreated carambola}

Water loss and solid gain occurred together in the process of OD. Due to water loss, the solid gain was also affected. The amount of water loss in all samples of carambola were recorded in Table 2. During OD process, water loss in carambola samples occurred due to moisture removal from the carambola tissues. In the other words, loss of water occured by diffusion through the skin of carambola and evaporation from the tissues in the fruits (Piyalungka et al., 2019). From Table 2, it can be stated that the glucose syrup concentration, its soaking time and temperature had effect on the water loss in the samples of carambola. Sample 3 showed the highest water loss, which was $62.58 \mathrm{~g}$, followed by Sample 2 and Sample 1, which were $44.18 \mathrm{~g}$ and $25.49 \mathrm{~g}$. All the tested samples were significantly different $(p<0.05)$. This result showed that increasing the variables used had caused an increase in the water loss for the samples of carambola. As the soaking concentration rose, it led to higher trans-membrane differences in the osmotic pressure and this caused higher water loss from the fruit tissues (Roopa et al., 2012). The higher the temperature used in the OD process, the viscosity of soaking solution produced at the end of the process will be reduced (Herman-Lara et al., 2019). From this study, the highest time used which was 60 min caused the highest water loss in the carambola. The efficiency of the OD process could be optimized by further drying process by a dehydrator as it ensures all the water contained in the fruits to be diminished.

\section{Total moisture content}

The moisture content of carambola chips was in the range of $13.21 \%$ to $49.57 \%$ and the values decreased among the three samples. From Table 3, Sample 1 had the highest $(p<0.05)$ moisture content 1 followed by Sample 2 and Sample 3. The moisture content of foods was linked to the loss of water by diffusion through the skin and by evaporation from the tissues in the fruits (Garcia et al., 2014). OD tends to reduce the moisture content of samples involved (Szparaga et al., 2019) by $30 \%$ to $70 \%$ (Raoult-Wack et al., 1991). A study conducted by Sulaeman et al. (2004) also revealed that the moisture content of their carrot chips varied from $1.96 \%$ to $2.68 \%$ according to the treatments used. This proved that high OA viscosity used will also produce low moisture content of chips. From this study, Sample 3 was the most preferable carambola chips as it contained the lowest moisture content than Sample 1 and Sample 2.
Texture analysis (hardness and crispiness)

From Table 4, Sample 1 was the hardest compared to Sample 1 and Sample 2 though the diffrence was not significant. Menawhile, Sample 1 and Sample 3 were significantly different $(p<0.05)$, while both of the samples were not significantly different with Sample $2(p>0.05)$. Based on the mean reasults, it also showed that Sample 3 was the crispiest, followed by Sample 2 and Sample 1. It is proved that the higher the variables used in OD process, the higher the rate of hardness and crispness of the carambola chips. When hardness of carambola chips increased, the crispness of carambola chips will also increase (Paula \& Conti-Silva, 2014). Sample 1 which contained the highest moisture

Table 2. The water loss for each sample of carambola

\begin{tabular}{ll}
\hline Samples & Water loss $(\mathrm{g})$ \\
\hline Sample $1^{*}$ & $25.49 \pm 0.38^{\mathrm{c}}$ \\
Sample 2**$^{* *}$ & $44.18 \pm 0.13^{\mathrm{b}}$ \\
Sample 3 $^{* *}$ & $62.58 \pm 0.93^{\mathrm{a}}$ \\
\hline
\end{tabular}

Sample $1^{*}$ : Carambola chips with $30^{\circ} \mathrm{B}$ glucose syrup concentration, 20 min soak time and $20^{\circ} \mathrm{C}$ soak temperature.

Sample $2^{\star *}$ : Carambola chips with $40^{\circ} \mathrm{B}$ glucose syrup concentration, 40 min soak time and $40^{\circ} \mathrm{C}$ soak temperature.

Sample $3^{* * *}$ : Carambola chips with $50^{\circ} \mathrm{B}$ glucose syrup concentration, $60 \mathrm{~min}$ soak time and $60^{\circ} \mathrm{C}$ soak temperature.

Table 3. Moisture content for each sample of carambola chips

\begin{tabular}{lc}
\hline Samples & Moisture content (\%) \\
\hline Sample $1^{*}$ & $49.57 \pm 0.02^{\mathrm{a}}$ \\
Sample 2* $^{* *}$ & $19.25 \pm 0.05^{\mathrm{b}}$ \\
Sample 3 $^{* *}$ & $13.21 \pm 0.05^{\mathrm{c}}$ \\
\hline
\end{tabular}

Sample $1^{\star}$ : Carambola chips with $30^{\circ} \mathrm{B}$ glucose syrup concentration, 20 min soak time and $20^{\circ} \mathrm{C}$ soak temperature.

Sample $2^{* *}$ : Carambola chips with $40^{\circ} \mathrm{B}$ glucose syrup concentration, 40 min soak time and $40^{\circ} \mathrm{C}$ soak temperature.

Sample $3^{* * *}$ : Carambola chips with $50^{\circ} \mathrm{B}$ glucose syrup concentration, $60 \mathrm{~min}$ soak time and $60^{\circ} \mathrm{C}$ soak temperature.

Table 4. Hardness and crispness for each sample of carambola chips

\begin{tabular}{lcc}
\hline Samples & Hardness $(\mathrm{kg})$ & Crispness $(\mathrm{kg} / \mathrm{sec})$ \\
\hline Sample 1 $^{*}$ & $0.12 \pm 0.06^{\mathrm{b}}$ & $4.80 \pm 0.69^{\mathrm{b}}$ \\
Sample 2 $^{* *}$ & $0.70 \pm 0.46^{\mathrm{ab}}$ & $6.75 \pm 1.72^{\mathrm{ab}}$ \\
Sample 3 $^{* \star *}$ & $1.39 \pm 0.72^{\mathrm{a}}$ & $9.43 \pm 1.47^{\mathrm{a}}$ \\
\hline
\end{tabular}

Sample $1^{*}$ : Carambola chips with $30^{\circ} \mathrm{B}$ glucose syrup concentration, 20 min soak time and $20^{\circ} \mathrm{C}$ soak temperature.

Sample $2^{\star *}$ : Carambola chips with $40^{\circ} \mathrm{B}$ glucose syrup concentration, 40 min soak time and $40^{\circ} \mathrm{C}$ soak temperature.

Sample $3^{* * *}$ : Carambola chips with $50^{\circ} \mathrm{B}$ glucose syrup concentration, $60 \mathrm{~min}$ soak time and $60^{\circ} \mathrm{C}$ soak temperature. 
content during OD process will produce the most wilted carambola chips when it was fried. This also showed that moisture content had a big role on the hardness and crispness of the chips and supported by Caetano (2018) who explained that crispness of chips were closely related to its moisture content.

\section{CONCLUSION}

From this study, it can be concluded that OD of carambola produced higher water loss and lower solid gain as glucose syrup concentration, soak time and soak temperature increased. The lowest water loss and solid gain of carambola recorded in this study were $25.49 \mathrm{~g}$ and $24.50 \mathrm{~g}$ while the highest solid gain were $62.58 \mathrm{~g}$ and $46.11 \mathrm{~g}$, respectively. The texture analysis in term of the highest hardness and crispness recorded were $1.39 \mathrm{~kg}$ and $9.43 \mathrm{~kg} / \mathrm{s}$, correspondingly. The OD of carambola can be further explored by using different types of OA to optimize the process.

\section{ACKNOWLEDGEMENTS}

The authors gratefully acknowledge Universiti Sains Islam Malaysia (USIM) for the financial assistance. The manuscript preparation was financially supported by Faculty Science and Technology (USIM) under the publication fund.

\section{REFERENCES}

Aida, S.A., Noriza, A., Haswani, M.M. \& Mya, S.M.Y. 2016. A study on reducing fat content of fried banana chips using a sweet pretreatment technique. International Food Research Journal, 23(1): 68 .

AOAC. 2005. Official Methods of Analysis, 18th Ed. AOAC International, Gathersburg.

Caetano, P.K., Mariano-nasser, F.A.D.C., MendonÇa, V.Z.D., Furlaneto, K.A., Daiuto, E.R. \& Vieites, R.L. 2018. Physicochemical and sensory characteristics of sweet potato chips undergoing different cooking methods. Food Science and Technology, 38(3): 434-440.

Chaudhari, A.P., Kumbhar, B.K., Singh, B.P.N. \& Narain, M. 1993. Osmotic Dehydration of Fruits and Vegetables. Indian Food Industry, 12: 2020 .
Chauhan, J.B. \& Kapfo, W. 2016. Effect of traditional sun drying on indigenous starfruit (Averrhoa carambola) from India. International Journal of Plant, Animal and Environmental Sciences, 6(1): 121-132.

Dasgupta, P., Chakraborty, P. \& Bala, N. 2013. Averrhoa Carambola: An Updated Review. International Journal of Pharma Research \& Review, 2(July): 54-63.

El-Aouar, A., Jr, L.B., Elizabeth, F. \& Murr, X. 2006. Influence of the Osmotic Agent on the Osmotic Dehydration of Papaya (Carica papaya L.). Journal of Food Engineering, 75: 267-274.

Garcia, C.C., Caetano, L.C., de Souza Silva, K. \& Mauro, M.A. 2014. Influence of Edible Coating on the Drying and Quality of Papaya (Carica papaya). Food and Bioprocess Technology, 7(10): 2828-2839.

Herman-Lara, E., Rodríguez-Miranda, J., HernándezSantos, B., Juárez-Barrientos, J.M., GallegosMarín, I., Solís-Ulloa, D. \& Martínez-Sánchez, C.E. 2019. Influence of pretreatments on oil absorption of plantain and cassava chips. Journal of Food Science and Technology, 56(4): 1909-1917.

Leelarungrayub, J., Yankai, A., Pinkaew, D., Puntumetakul, R., Laskin, J.J. \& Bloomer, R.J. 2016. A Preliminary Study on the Effects of Starfruit Consumption on Antioxidant and Lipid Status in Elderly Thai Individuals. Clinical Interventions in Aging, 11: 1183-1192.

Lopez, S.V. \& Moreira, R.G. 2019. Increased Phenolic Compounds in Potato Chips Vacuum Impregnated with Green Tea. Journal of Food Science, 84(4): 807-817.

Macoboy, S. 1982. Trees for Fruit and Foliage. Lansdowne Press, Sydney, 161 pp.

Paula, A.M. \& Conti-Silva, A.C. 2014. Texture Profile and Correlation between Sensory and Instrumental Analyses on Extruded Snacks. Journal of Food Engineering, 121: 9-14.

Piyalungka, P., Sadiq, M.B., Assavarachan, R. \& Nguyen, L.T. 2019. Effects of osmotic pretreatment and frying conditions on quality and storage stability of vacuumfried pumpkin chips. International Journal of Food Science \& Technology, 54(10): 2963-2972.

Raoult-Wack, A.L., Guilbert, S., Maguer, M.L. \& Rios, G. 1991. Simultaneous water and solute transport in shrinking media-part 1: application to dewatering and impregnation soaking process analysis (osmotic dehydration). Drying Technology, 9(3): 589-612. 
Rodríguez-Miranda, J., Martínez-Sánchez, C.E., Hernández-Santos, B., Juárez Barrientos, J.M., Ventura-Báez, E.G. \& Herman-Lara, E. 2018. Effect of enzymatic pretreatment on the physical quality of plantain (Musa ssp., group AAB) employing airflow reversal drying. Journal of Food Science Technology, 55(1): 157-163.

Roopa, N., Chauhan, O.P., Raju, P.S., Das Gupta, D.K., Singh, R.K.R. \& Bawa, A.S. 2012. Process Optimization for Osmo-dehydrated Carambola (Averrhoa carambola L.) Slices and its Storage Studies. Journal of Food Science and Technology, 51(10): 2472-2480.

Szparaga, A., Stachnik, M., Czerwiñska, E., Kocira, S., Dymkowska-Malesa, M. \& Jakubowski, M. 2019. Multi-objective optimization based on the utopian point method applied to a case study of osmotic dehydration of plums and its storage. Journal of Food Engineering, 245: 104-111.
Sulaeman, A., Giraud, D.W., Keeler, L., Taylor, S.L. \& Driskell, J.A. 2004. Effect of Moisture Content of Carrot Slices on the Fat Content, Carotenoid Content, and Sensory Characteristics of Deepfried Carrot Chips. Journal of Food Science, 69(6): C450-C455.

Tiwari, R.B. 2005. Application of Osmo-Air Dehydration for Processing of Tropical Fruits in Rural Areas. Indian Food Industries, 24(6): 62-69.

Yadav, A.K. \& Singh, S.V. 2014. Osmotic Dehydration of Fruits and Vegetables: A Review. Journal of Food Science and Technology, 51(9): 1654-1673. 
